NBER WORKING PAPER SERIES

\title{
WHO LIVES IN THE C-SUITE? ORGANIZATIONAL STRUCTURE AND THE DIVISION OF LABOR IN TOP MANAGEMENT
}

\author{
Maria Guadalupe \\ Hongyi Li \\ Julie Wulf \\ Working Paper 17846 \\ http://www.nber.org/papers/w17846 \\ NATIONAL BUREAU OF ECONOMIC RESEARCH \\ 1050 Massachusetts Avenue \\ Cambridge, MA 02138 \\ February 2012
}

We would like to thank Erik Brynjolfsson, David Collis, Wouter Dessein, Bob Gibbons, Shane Greenstein, Don Hambrick, Connie Helfat, Bruce Harreld, Anne Marie Knott, Kristina McElheran, Paul Oyer, Heikki Rantakari, Jim Rebitzer, Julio Rotemberg, Raffaella Sadun, Tano Santos, John Van Reenen, David Yoffie, Tim Van Zandt, and especially Jim Dana for very helpful discussions. Thanks also to seminar participants at IESE, LBS, the NBER Organizational Economics meeting, UCLA, Washington University, HBS strategy conference, HBS brown bag and to Erik Brynjolfsson and Lorin Hitt, for the Harte Hanks data. The views expressed herein are those of the authors and do not necessarily reflect the views of the National Bureau of Economic Research.

NBER working papers are circulated for discussion and comment purposes. They have not been peerreviewed or been subject to the review by the NBER Board of Directors that accompanies official NBER publications.

(C) 2012 by Maria Guadalupe, Hongyi Li, and Julie Wulf. All rights reserved. Short sections of text, not to exceed two paragraphs, may be quoted without explicit permission provided that full credit, including (๑) notice, is given to the source. 
Who Lives in the C-Suite? Organizational Structure and the Division of Labor in Top Management Maria Guadalupe, Hongyi Li, and Julie Wulf

NBER Working Paper No. 17846

February 2012

JEL No. D22,J31,L2,M12,M5

\begin{abstract}
$\underline{\text { ABSTRACT }}$
This paper shows that top management structures in large US firms radically changed since the mid-1980s. While the number of managers reporting directly to the CEO doubled, the growth was driven primarily by functional managers rather than general managers. Using panel data on senior management positions, we explore the relationship between changes in executive team composition, firm diversification, and IT investments-which arguably alter returns to exploiting synergies through corporate-wide coordination by functional managers in headquarters. We find that the number of functional managers closer to the product ("product" functions i.e., marketing, $R \& D$ ) increase as firms focus their businesses, while the number of functional managers farther from the product ("administrative" functions i.e., finance, law, HR) increase with IT investments. Finally, we show that general manager pay decreases as functional managers join the executive team suggesting a shift in activities from general to functional managers-a phenomenon we term "functional centralization."
\end{abstract}

Maria Guadalupe

Graduate School of Business

Columbia University

3022 Broadway, Uris Hall 624

New York, NY 10027

and NBER

mg2341@columbia.edu

Hongyi Li

MIT Sloan School of Management

100 Main Street, E62-513

Cambridge, MA 02142

hongyili@mit.edu
Julie Wulf

Harvard Business School

Morgan Hall 241, Soldiers Field Road

Boston, MA 02163

jwulf@hbs.edu 


\section{Introduction}

"We learned from experience that work of higher quality could be obtained by utilizing, corporation-wide, the highly developed talents of the [functional] specialists.”

Alfred P. Sloan, Jr. “My Years with General Motors” (1963)

Modern corporations are run by a team of executives that go beyond the Chief Executive Officer (CEO). It is by now a well established fact that the size of the CEO's executive team--as defined by the managers that report directly to the CEO and commonly referred to as the C-Suite--has increased dramatically in recent decades (Rajan and Wulf, 2006). Yet we know little about the composition of the top team -- even though it is the governing body that sets firm strategy, coordinates activities and allocates resources across business units, decisions that are critical to firm performance. Moreover, the executive team is the focus of extensive research on top management teams (TMT) by management scholars (Hambrick and Mason, 1984). To explore changes in the organizational structure at the top, we use a unique panel dataset rich in details of managerial job descriptions, reporting relationships and compensation structures for senior management positions in large US firms over two decades (19862006). We are the first to document the dramatic increase in the number of functional managers in the executive team. The size of the team in these firms doubled over the time period from 5 to 10 positions, with approximately three-fourths of the increase attributable to functional managers (e.g., Chief Financial Officer, Chief Marketing Officer, Chief Human Resource Officer) rather than general managers. ${ }^{1}$ After documenting this novel fact, we use our firm panel-dataset of 300 large US firms to study the drivers of changes in firm organizational structure, as reflected in the top management team. This analysis will uncover how firms adapt their organizational structure to implement changes in strategies.

Firm choices about hierarchical structure and task allocation across managers are critical to current formal theories of firm organization (e.g., Garicano, 2000; Harris and Raviv, 2002; Hart and Moore, 2005; Dessein and Santos, 2006; Dessein, Garicano and Gertner, 2011). The relevant tradeoff that we focus on is whether a firm assigns activities to functional managers to coordinate corporate-wide functions and exploit synergies (e.g., Chief Marketing Officer and marketing activities) versus assigning activities to general managers responsible for business units who may have better local information or incentives. One well-known example illustrating this tradeoff is Lou Gerstner's turnaround of IBM in the mid-1990s. Before Gerstner was hired as CEO, IBM was a highly decentralized organization operating in related information technology businesses, but with little coordination across businesses. The executive team was comprised primarily of autonomous general managers of business units (e.g., mainframes) and

\footnotetext{
${ }^{1}$ In this paper, we define the executive team or members of the C-Suite (e.g., Groysberg, Kelly, and MacDonald,
} 2011) as the positions that report directly to the CEO in the organizational hierarchy or the CEO's span of control. 
very few functional managers. Gerstner joined in 1993 and deliberately "centralized" activities to turnaround the firm's massive losses that he later attributed to the "balkanized IBM of the early 1990's."2 Not long into his tenure, Gerstner dramatically changed the firm's strategy to one based on an integrated product and service offering to customers (“One IBM”). Since the new strategy required extensive coordination across business units, Gerstner reorganized the top team and added functional managers to facilitate corporate-wide coordination (see Exhibit 1). For example, he created a Chief Marketing Officer position (CMO) and filled the position with an external hire. Historically, all marketing activities were performed within the individual business units, which led to 100 marketing campaigns, overseen by various advertising agencies. ${ }^{3}$ To better coordinate marketing activities across all businesses and unify IBM's global brand, the new CMO consolidated all of IBM's buying, planning and direct marketing in the hands of one advertising agency.

The addition of a CMO to IBM's executive team was a structural choice to centralize marketing activities at the corporate level to implement the "One IBM" strategy. In a large sample of researchintensive firms, and motivated by the evolution of Du Pont's organization of R\&D since the 1920's, Argyres and Silverman (2004) classify firms as having centralized R\&D structures when "there is a single executive in charge of the firm's research activities who reports directly to a corporate-level executive such as the CEO or President (pg. 931)”. In general, firms place functional managers in the executive team in order to centralize decisions related to their function, to coordinate activities across business units, and to involve the function in strategic decision making with the CEO (Menz, 2007) -- all broadly related to the objective of coordinating activities, realizing synergies and improving efficiency. In what follows, we will loosely refer to the presence of a functional manager reporting to the CEO as "functional centralization,” acknowledging that some activities may still be performed within the business unit.

To explain the shift in the composition of the top team towards increased functional centralization since the mid-1980s, we consider two important trends in the environment in which firms operate that are potentially relevant to a firm's ability to exploit synergies. First, large US firms have become less diversified in response to increased global competition and demanding capital markets. Second, firms have dramatically increased investments in information technology as costs have declined. Existing theories explain why these trends can have an effect on the composition of the top team. As firms narrow their business portfolios, they increase opportunities for synergies (e.g., Hill, Hitt and Hoskisson, 1992; Helfat and Eisenhardt, 2004; Hart and Moore, 2005) and as they increase IT investments, they reduce communication costs and hence the costs of exploiting synergies (e.g., Dessein and Santos, 2006; Cremer, Garicano and Prat, 2007). Both trends could lead to additional corporate-level functional managers as the

\footnotetext{
${ }^{2}$ Gerstner, Louis, Jr., “Who Says Elephants Can’t Dance,” Harper Collins, New York, p. 77, 2002.

${ }^{3}$ International Business Machine (IBM), 1994 Annual Report, p.6.
} 
gains from coordinating activities across business units increase and the costs of coordination decline. Yet, these simple explanations are not supported by the data. Interestingly, we find that the relationships vary by type of functional manager, and that it is only by distinguishing between types of managers that we can map the theoretical predictions to the data.

In particular, and in line with the common parlance exemplified in Chandler (1991) and Porter (1985), ${ }^{4}$ we distinguish between two types of headquarter functions: (i) "product” or front-end functions (e.g., marketing, R\&D) that are closer to both customers and product markets and that require information that is product-specific and (ii) "administrative" or back-end functions (e.g., finance, legal, human resources) where information is less product-specific. Our most novel set of results is that we find different relationships between types of functional managers and changes in firm diversification and IT investments. First, at odds with a naive application of the classic synergy explanation, firms do not increase the number of functional managers as they narrow firm scope. Instead, we find that as firms become more focused, they increase product functional managers (e.g., CMO), but there is no effect on administrative functional managers (e.g., CFO). Second, there is no simple relationship between changes in functional managers and IT investments; instead, it varies by type of function. The number of administrative functional managers is increasing in IT-intensity, but there is no effect of IT on product functional managers. Third, to understand more fully the differential roles of executives in headquarters, we analyze how pay of functional managers and general managers changes as the structure of the top team changes. Using position-level regressions, we find that division manager pay (general manager) declines with the number of functional managers that report directly to the CEO, and that this relationship is driven by the number of product functional managers, not administrative functional managers.

Notice we identify all effects by exploiting not only differences within firms and positions over time, but also differences between types of positions within firms. The dataset is also unique since it captures the reporting relationships of executive positions (i.e., CEO's span of control) thereby allowing a precise definition of the top team that does not rely on titles and other measures that can vary significantly across firms and over time.

We interpret this set of findings as being broadly consistent with different types of functional managers in the executive team performing activities that vary in the nature of the information they use: in particular, the relative importance of product-specific information. Product functions (e.g., marketing) use information that is product-specific and more difficult to aggregate across businesses. In contrast, administrative functions (e.g., finance) use information that is easier to aggregate because it is less

\footnotetext{
${ }^{4}$ Chandler (1991) makes a distinction between two types of functions of the headquarters unit in multi-business firms: entrepreneurial (value-creation) and administrative (loss prevention). In the strategy literature, Porter (1985) distinguishes between two types of activities within functions: support (finance, HR, systems) and primary (manufacturing, inbound and outbound logistics, sales, after-sales support).
} 
product-specific. ${ }^{5}$ So, as firms increase focus, they “centralize” product functions by placing a functional manager in the top team because of greater potential for synergies and gains from coordination across business units; firms investing in IT "centralize” administrative functions because of the relative ease and lower costs of communicating information from business units. ${ }^{6}$ One could also interpret this result as firms centralizing functions that use "hard"/codifiable information (Stein, 2002) when they invest in IT, if administrative functions use relatively more "hard" information than product functions. While we do not observe the allocation of activities in our data, our findings on pay suggest that the role of the functional manager changes as the position joins the executive team, and that functional managers serve as substitutes for general managers in product functions, but not in administrative functions. Taken together, our results are broadly consistent with "functional centralization."

The types of managerial positions that report directly to the CEO also reflect the underlying organizational structure of a firm. The most common form until the 1920s was the U-form or functional structure, with a top team comprised of functional managers responsible for the corporate-wide activities of their specialized function (e.g., finance, legal, marketing, manufacturing). In contrast, the M-form or multidivisional structure, included general managers in the top team who were responsible for a broad range of activities and the profit and loss of the business unit. ${ }^{7}$ The M-form, hailed by Williamson (1975, 1985) and documented by Chandler (1962), largely replaced the U-form and continued to remain prevalent among large US firms through the early 1990s (Fligstein, 1990). One important contribution of this paper is that we provide evidence that the structure of executive teams in large US firms today is dramatically different than that of the traditional M-form organization.

Taken together, our findings have important implications for both the formal models of organizational structure in economics and the extensive research on top management teams in the management literature. Formal models emphasize organizational structure, but are silent on the composition of the top team of executives. They do not distinguish between general and functional managers much less between different types of functional managers. Our results highlight the importance of giving more prominence to managers performing tasks with very different characteristics/information needs. In contrast, the TMT literature focuses solely on the top management team and emphasizes the diversity in executive characteristics and demographics, but doesn't consider the formal structure or

\footnotetext{
${ }^{5}$ Chandler's (1991) description of the finance function is consistent with this view: "Its functions were somewhat less product-specific...” (pg. 33)

${ }^{6}$ Relatedly, McElheran (2010) shows that the trade-off between local adaptation and coordination is relevant for the IT purchasing function. Bloom, Garicano, Sadun and Van Reenen (2010) show that communication and information technology have different effects on the propensity of firms to decentralize, but they focus mainly on lower levels of the hierarchy -plant managers. Neither of these papers considers the composition of the top management team.

${ }^{7}$ The general office was comprised of the top executive officers responsible for determining the long-term strategic vision and exercising overall financial control, but had little involvement in the operations of the business units.
} 
composition of the types of managerial positions that comprise the team. ${ }^{8}$ Our results show that making distinctions between types of managers when considering the composition of the executive team is not only important in a world that is richer than current theories, it is also crucial for strategy implementation within firms.

\section{II: Changes in the Composition of Top Management Teams}

\section{II.A: Characterizing the Top Team: General Managers and Types of Functional Managers}

In this sub-section, we define functional and general manager positions in the executive team and describe the novel trend documented in this paper, i.e., that the growth in the size of the executive team was driven primarily by functional managers rather than general managers.

We define the top management team of an organization as the CEO and the managers that report directly to him. To make concepts concrete, let us refer to the top team structure for IBM in 1994 (Figure 1). At the time, Lou Gerstner, the CEO, had fourteen direct reports that can be classified into two broad types of positions: functional managers and general managers. Functional managers -- or corporate staff -are responsible for corporate-wide activities of their specialized function (e.g., finance, legal, marketing, $R \& D)$. In contrast, general managers -- or line managers -- are concerned with a broad range of functional activities within their business units and typically have profit and loss responsibility. Gerstner's executive team included nine functional managers and five general managers including the general managers of the personal computer business (General Manager --Personal Systems ) and the mainframe business (General Manager --Systems), among others.

Not surprisingly, corporate-level functional managers perform different activities that vary by function. For example, in the marketing function as illustrated in IBM, CMO responsibilities include “leading the company’s marketing organization; uniting and strengthening various departments' own marketing plans; directing global marketing efforts, including branding, product marketing, and customer relationship marketing.” (Nath and Mahajan, 2008, pg. 67). As another example, the corporate R\&D function of Du Pont involved "coordination of research, avoidance of duplication of effort, promulgation of results which are of interest to more than one department.” (Hounshell and Smith, 1988, pg 108). Finally, for the finance function, Chandler's (1991) description states that: “tasks were to coordinate the

\footnotetext{
${ }^{8}$ While much of the empirical research in management on top management teams (TMT) (Hambrick \& Mason, 1984; Finkelstein, Hambrick, and Cannella, 2009) focuses on the characteristics of the individual manager (e.g., tenure, education, experience), we focus on the composition of the types of positions instead of the executives filling them. More recent research in management has analyzed individual TMT positions (e.g., COO, CMO, CIO) in corporate headquarters, yet there is no evidence on functional TMT members as a group (e.g., Collis, Young and Goold, 2007; Menz, 2011).
} 
flow of funds through the enterprise's many units and to provide a steady flow of information to enable top management to monitor performance and allocate resources” (Pg. 33). ${ }^{9}$

As mentioned earlier, functional managers can be further classified into two categories depending on their proximity to the product (Porter 1985; Chandler, 1991). In our data, we classify the following functions as "product” functions: Marketing (Chief Marketing Officer, CMO), Research \& Development (Chief R\&D Officer), Sales and Manufacturing. We classify the following functions as "administrative” functions: Finance (Chief Financial Officer, CFO), Law (General Counsel), Human Resources (Chief Human Resources Officer, CHRO), Information Technology (Chief Information Officer, CIO), Strategy (Long-Range Planning \& Business Development) and Public Relations (PR or Communications Officer). IBM’s Gerstner had three product functional managers and six administrative functional managers.

In addition to using different types of information to perform activities, product and administrative functional managers at the corporate level differ in the type of activities that they perform. Product functional managers are more involved in the coordination of activities across business units to generate revenue, while administrative functional managers generally are more involved in the monitoring or auditing of functions across business units to ensure compliance with corporate policies.

As mentioned earlier, while the span of control of the CEO has increased substantially since mid1980, less is known about the changes in the composition of the top executive team. Figure 2 shows the evolution of the top management team in our sample of large US firms (see data description in Section III). We plot the average size of the top team (CEO span of control) in our data (1986-1999) and for a more recent time period using data collected from the Conference Board for 43 firms (we obtained the organizational chart for these firms for one year between 2004 and 2008). To minimize bias from using an unbalanced panel, the figures documenting trends are based on the sample of firms that appear for at least 10 years over the sample period (if we limit the sample to only the 43 firms for which we have data in the later period, the pattern over the time period is qualitatively similar). The average CEO span of control doubled from approximately 5 to 10 positions. But, the novel trend documented in this paper is that the composition of the executive team shifted toward more functional managers. The average number of functional managers reporting directly to the CEO increased from 3.1 in the late 1980s to 6.7 in the mid 2000s - an increase of 3.6 positions. This is significantly larger than the 1.3 position increase in general

\footnotetext{
${ }^{9}$ In addition, it is well-known that managers at the top of the hierarchy have extensive visibility (both internal and external) and have direct access and interaction with the CEO, arguably the scarcest and most valuable human capital resource (Bandiera, Prat, Sadun and Wulf, 2011). Managers reporting directly to the CEO often comprise the Executive Committee which is the most influential decision-making body in large organizations. According to CEOs, managers that report directly to the CEO tend to "have a seat at the table" which means that they are important and influential members of the senior management team (Wulf, 2011).
} 
manager positions (from 1.6 to 2.9). This means that, on average, approximately three quarters of the five position increase is attributed to functional managers. ${ }^{10}$

To give a better sense of the details behind these averages, in Table 1 we report data on select individual positions that comprise the executive team. Column 1 reports the fraction of firms in the sample where the position reports directly to the CEO and shows that CEOs in our sample had a higher number of administrative functions (especially finance, legal, HR) reporting directly in comparison to product functions. Columns 2 onwards report the (unconditional) correlation coefficients between positions reporting to the CEO. We find that functional positions that we classify as administrative appear together in the executive team (i.e., have large positive correlation coefficients), while the positions that we classify as product functions also appear together. For example, CFO and General Counsel tend to appear together in the top management team (0.29 correlation), and so do Sales/Marketing and Manufacturing (0.21 correlation). These correlations provide some support for our ex-ante classification of positions into the two types. In section IV, we will analyze how the composition of the top management team changed over time within firms in response to changes in firm scope and IT investments.

\section{II.B: Diversification, IT, and Changes in the Composition of Top Management Teams}

In this sub-section we provide a simple framework to think about our findings on the firm's organizational choices regarding the number of functional managers in the executive team. A key point that we emphasize throughout this section is that the decision to add a given functional manager at the top depends crucially on the nature of the information required to perform that functional activity.

Firms perform activities associated with various functions (marketing, sales, finance, etc), each of which requires information from one or more business units. We observe firms changing over time in their choice to include a functional manager in the executive team. Therefore, the simple organizational choice we consider is whether to have a functional manager perform that activity versus leaving the activity at the business unit. To make this choice, the firm needs to consider the information required to efficiently perform functional activities. The disadvantage of having the functional manager perform the activity is that it is costly to communicate local information from the business unit (where the local information resides) to the functional manager. The advantage is that synergies can be achieved more efficiently if the functional manager performs the activity and coordinates across all business units (there

\footnotetext{
${ }^{10}$ There are various idiosyncratic reasons why functional manager positions have become more important over time. For example, the rise of the CFO position is related to the increasing complexity of financial markets and changes in accounting rules (Zorn, 2004). Or, as companies become more customer-focused and marketing techniques grow in sophistication, Chief Marketing Officers (CMOs) play a more important role in senior management. CEOs may also signal greater strategic importance of certain functions both inside the organization and to key external constituents through their choice of direct reports.
} 
are various reasons for this - for example, functional managers can better coordinate activities across business units or may have better incentives to perform synergistic activities, as in Dessein, Garicano and Gertner, 2011). Note that "synergies” can encompass a large number of phenomena: economies of scale, economics of scope, reduced cannibalization across business units (i.e., diseconomies of scope or transaction costs), better allocation of capital and cross-subsidization across business units, etc.

First, let's consider how firm scope or diversification affects the decision to allocate activities to a functional manager. In focused firms with related businesses, there are more opportunities for synergies and hence greater gains from coordination across businesses; in general, we would expect more functional managers in focused firms. But, the effect should be quite different for product versus administrative functions because they use different types of information. We argue that product functions use information that is highly product specific - so that the format, processing, and interpretation of information for product functions differs across business units - while administrative functions use little or no product-specific information - so that information for administrative functions is relatively homogenous across business units. Therefore, focused firms should have more product functional managers to exploit corporate-wide synergies because the information-which is product-specific--is more similar when business units are related. Since administrative functions use information that is not product-specific (i.e., information whose format and interpretation does not differ across business units), diversification choices should not matter at all for those functions. ${ }^{11}$

Next, let us consider the role of IT in the choice to allocate an activity to a corporate-level functional manager. One characteristic feature of IT investments is that they reduce communication and coordination costs (Garicano, 2000; Dessein and Santos, 2006; Cremer, Garicano and Prat, 2007; Bloom et al, 2010). IT therefore can exploit synergies by facilitating information processing by functional managers-i.e., it is easier for them to acquire, communicate and analyze information across business units in performing functional activities. As before, differences emerge across functions depending on the type of information used: in this case, the less product-specific (and the more similar across business units) the information used by the function, the larger the potential synergies that can be realized with higher IT. Therefore, as firms increase IT investments, they increase the number of administrative functional managers since they use less product-specific information. In contrast, product functional managers only respond to IT in focused firms. IT can also facilitate communication between general managers as in Dessein and Santos (2006); in this case, we would have less need for corporate-wide coordination and expect fewer functional managers in the top team.

\footnotetext{
${ }^{11}$ This tendency to centralize/integrate activities to capture synergies (broadly construed) is similar to Rotemberg (1999), Hart and Moore (2005), Qian, Roland and Xu (2006), and Dessein, Garicano and Gertner (2011).
} 
In sum, the returns to allocating an activity to a corporate-level functional manager rather than a general manager in charge of a business unit depend on the degree to which information across business units can be used to exploit synergies. This varies across type of function and the nature of the information that is required to perform functional activities: in particular, the relative importance of product-specific information.

\section{Data Sources and Description}

In order to analyze the drivers of the observed increased presence of functional managers in the top management team described in Section II.A, we draw on a number of different datasets. First, our main dataset is based on a confidential compensation survey conducted by Hewitt Associates, a leading human resources consulting firm specializing in executive compensation and benefits. This dataset allows us to identify how the number and type of positions that report directly to the CEO change over time. The dataset records information on managerial positions at the top of the organization, their compensation, their title/job description and who the individual reports to. Notice that the title/job description is categorized by Hewitt in order to make positions comparable across firms. That is, even if the same position has different titles in different firms, Hewitt will group them into positions that share job descriptions and responsibilities. This is essential for our study, since it implies that we can easily compare positions and their evolution across firms over time. In addition to the positions defined earlier, the dataset also records information on the Chief Executive Officer (CEO), the Chief Operating Officer (COO) and the Chief Administrative Officer (CAO). With this dataset we are able to define how many positions report directly to the CEO (span of control or the members of the executive team) and observe what positions those are.

The sample spans the 1986-1999 period and includes around 300 firms of which $69 \%$ are in manufacturing, and 31\% are in services. The firms are typically leaders in their sector and representative of the Fortune 500 firms (see Rajan and Wulf, 2006 for a detailed sample description). ${ }^{12}$ Hewitt also records detailed compensation information for all positions, but we were only able to obtain the detailed data for a subset of positions. These include the CEO, Division Managers, the CFO, General Counsel and the Chief Human Resources Officer. For these positions, we have information on the level of salary, bonus and long-term compensation (this includes the Black-Scholes value of stock options grants, restricted stock and other long-term incentives).

\footnotetext{
${ }^{12}$ Rajan and Wulf (2006) describes the sample representativeness relative to Compustat firms, discusses concerns about selection, and potential misreporting in the survey. It concludes that the sample is representative of large, Fortune 500 firms that are leaders in their sectors.
} 
This unique dataset allows us to characterize the composition of the top executive team, as defined by the positions that report directly to the CEO, and analyze how the composition changes over 14 years. So, the definition and measure of our executive team is not dependent on titles, but instead on reporting relationships. This is not possible in any of the existing datasets we are aware of. However, in spite of its richness, our dataset has some limitations. First, functional positions may exist in other places of the organization, and not report directly to the CEO (in that case, because we focus on top executive team positions, we would under-estimate the extent of centralization or integration of functions). Second, we cannot definitively answer the question of whether the increase in functional positions at the top comes from newly created or existing positions. For some functions (finance, law and HR), we know whether the position exists and the reporting level of the position; but, we don't have this information for all functional positions. Finally, while the number of functional managers that report directly to the CEO is arguably related to the need to realize synergies within the firm, we do not observe how these synergies are realized, and in particular if the changes in functional managers are associated with changes in the allocation of activities, decision making, monitoring or aggregation of information towards the functional manager (and away from general or division managers).

We constructed a set of variables that measure the degree of diversification within firms. The first variable uses Compustat Segment data to measure firm entropy as defined in Palepu (1985) and conceptualized by Rumelt (1974). Intuitively, firm entropy measures the extent of diversification as captured by the different 2-digit SIC segments the firm operates in. We compute Palepu's measure for unrelated diversification, It is a transformation of a Herfindahl index (sum of squared shares of segment sales to firm sales) across different two-digit SIC segments reported by the firm that captures the extent of relatedness of the businesses the firm operates in. ${ }^{13}$ The higher the entropy/unrelated diversification measure, the more diversified the firm is. The second set of diversification variables, measure the degree of diversification/relatedness not just by whether two firm segments are close as defined by the SIC code, but by whether they use products that are related in Input-Output tables. Fan \& Lang (2000) calculate inter-industry relatedness coefficients using input-output commodity flow tables and construct two basic measures of relatedness: vertical and complementarity. The vertical relatedness measure captures the extent to which the segments the firm operates in are inputs to one another, as defined in the Input-Output tables. ${ }^{14}$ The higher the vertical relatedness value the more related the firm's businesses, along the

\footnotetext{
${ }^{13}$ Unrelated diversification is the weighted average of all 2-digit SIC group share in sales, i.e. the summation of the share multiplied by the log of the inverse of the share. This measure is widely used (e.g., Hill, Hitt, and Hoskisson, 1992 for an early example).

${ }^{14}$ Vertical relatedness is the dollar value of industry i's output required to produce 1 dollars' worth of industry j's output, as stated in input-output tables (we use coefficients based on 1992 US input-output tables). Forward vertical relatedness is when $i$ is the secondary segment and $\mathrm{j}$ is the primary segment. Backward vertical relatedness is the
} 
production chain. For example, since semiconductors are an important input into personal computers, firms that operate in both sectors would score high on the vertical relatedness measure. The complementarity measure, in turn, captures whether the businesses the firm operates in are all inputs into the same, common industry, or alternatively whether they source their products from the same common industry. ${ }^{15}$ For example, a firm that operates in both semiconductors and plasma screens would score high on the complementarity measure since these are both inputs into personal computers. The higher the complementarity value, the more related the firm's businesses.

We also obtain information on IT investment at the firm-year level from the Harte-Hanks database (see details in Bresnahan, Brynjolfsson and Hitt, 2002). The database reports the number of personal computers in use in each firm in a given year, so that we can define IT-intensity of the firm as the number of PCs per employee. Since our sample covers the 1986-1999 period, this variable is particularly meaningful, given that this is the period where PC prices were falling and firms started adopting the new technology (Dunne et al, 2004). We exploit the panel nature of our dataset and the differential rate of adoption by different firms. In our use of this variable, we expect to capture the overall IT-intensity within the firm, including not just PCs themselves, but also other aspects of IT that are correlated with hardware, such as software, Enterprise Resource Planning (ERP) or different types of technologies that improve communication. While we are not able to distinguish between investments in hardware, software or communication technology, from 1993 onwards, the dataset also records the number of Local Area Network nodes. A Local Area Network (LAN) is a communication network that connects several devices and provides a means for information exchange among those devices. The "nodes" are the devices connected to the network that can directly exchange information and communicate. Therefore the number of LAN nodes is a better measure of IT as a communicationimproving investment. ${ }^{16}$

Finally, using accounting information from Compustat data we construct a number of control variables such as firm size (ln sales and ln employment), firm internationalization (defined as the ratio of sales by foreign segments to total sales, from Compustat Segment data), the average industry price cost margin at 3 digit SIC as an inverse measure of product market competition and R\&D intensity (R\&D over

reverse. We denote the primary segment as the segment with the most sales. Our vertical relatedness measure is the simple average of the two.

${ }^{15}$ Following Fan \& Lang (2000), we compute the percentage of an industry's output supplied to each intermediate industry, denoted $b_{i k}$. For each pair of industries $i$ and $j$, compute the simple correlation between $b_{i k}$ and $b_{j k}$ across all $\mathrm{k}$ except $\mathrm{i}$ and $\mathrm{j}$. Forward complementarity measures the overlap in markets to which a firm's various segments sells its products. Backward complementarity measures the overlap in markets for the input industries of the firm's segments. Out complementarity measure is the simple average of both measures.

${ }^{16}$ Bloom, et al, (2010) also uses Harte-Hanks data for a cross-section of firms in 2006. In that period Harte-Hanks collected information on the types of software adopted such that the authors are able to distinguish between information technology and communications technology. Unfortunately such information is not available in our time period (a 14 year panel). 
firm sales, where missing $R \& D$ is considered as zero). We include these as controls, because as product markets globalize and become more competitive, and US firms increasingly differentiate products, we might expect firms to change the structure of the top team for other reasons.

\section{Results: Top Management Team Composition, Diversification, and IT}

The empirical analysis in what follows relies on the panel nature of our dataset for identification to identify the simultaneous changes in scope, IT investments and organizational decisions. ${ }^{17}$ We observe firms for up to 14 years, and we have information on changes in the structure of the top management team (defined by who reports directly to the CEO) along with measures for firm diversification and ITintensity. We also have detailed pay information for a subset of positions within firms over time. Therefore, we are able to control for unobserved firm heterogeneity and do not have to rely on crosssectional relationships to identify our results, thus improving on the literature that relies on cross-sectional evidence. $^{18}$

\section{IV.A. Firm Diversification, IT, and the Composition of the Top Management Team}

To study the correlates of executive team composition, we exploit the panel nature of our dataset. The basic structure of our empirical specification will be as follows:

$$
Y_{i t}=\alpha+\delta D I V E R S I F_{i t}+\beta I T_{i t}+X_{i t}{ }^{\prime} \theta+d_{t}+d_{i}+\varepsilon_{i t}
$$

Where the dependent variable $Y_{i t}$ will be the number of managers reporting to the CEO (in total, and by type --general or functional) in firm $i$, and year t. DIVERSIF $i t$ and $I T_{i t}$ are the diversification and ITintensity measures respectively, $X_{i t}$ are a large set of control variables: firm size (ln firm sales), the number of segments the firm operates in, the fraction of sales by foreign subsidiaries, the average pricecost margin in the industry as an (inverse) measure of product market competition, R\&D intensity

\footnotetext{
${ }^{17}$ Relatedly, a number of papers have documented that the complementarity between IT and certain organizational choices (e.g. Bresnahan, Brynjolfsson and Hitt, 2002;Bartel, Ichiowski and Shaw, 2007). The organizational choice we focus on here is the composition of the top management team.

${ }^{18}$ While we cannot argue that the relevant independent variables of interest (degree of firm diversification or IT investments) are purely exogenous, there are some clear exogenous forces (falling price of IT; globalization of trade and production and increasing competition) driving changes in these variables. However, it is difficult to find instruments that vary over time and by firms/industries. And even if we had such instruments, it would be hard to argue that they satisfy the exclusion restriction (that they only affect organizational choices through the instrumented variable). This is a common problem in this kind of work, so we rely on within firm and across position correlations to identify our results in this paper. For a reduced form analysis, with exogenous variation and arguably causal effects of competition on organizational structure, see Guadalupe and Wulf (2010).
} 
measured by total R\&D expenses over sales, and controls for whether the firm has a CAO or a COO. $d_{t}$ are year dummies and $d_{i}$ are firm fixed effects.

Table 3 explores the relationship between the size and structure of the top management team on the one hand and diversification choices and IT investments on the other. The dependent variable in Column 1 is the total number of managers that report directly to the CEO (CEO span of control). Columns 2 to 5 split the total number of managers into the different types. First, we consider general managers (Column 2), i.e. managers responsible for a broad set of functional activities within their business unit; Second, functional managers (Column 3), i.e. managers responsible for corporate-wide activities for a specific function; And even further, we distinguish between types of functional managers, i.e., product (front-end) functional managers (Column 4), that use relatively more product-specific information vs. administrative functional managers (back-end functions) that use relatively less productspecific information (Column 5).

Column 1 shows that unrelated diversification is positively related to the size of the top team: diversifying firms increase the number of positions reporting to the CEO. In contrast, IT investments (as measured by the number of PCs per employee) are not significantly related to team size. However, as we shall see, the relationships between the composition of the top team and diversification and IT investments systematically vary by type of position. Column 2 shows that the number of general managers reporting directly to the CEO is positively related to firm diversification, but unrelated to IT investments. In fact, the estimate for IT is negative, suggesting that if anything, there are fewer general managers in the top team as the firm invests in IT. In contrast, Column 3 shows the opposite relationship for functional managers: the number of functional managers is positively related to IT investments, but unrelated to firm diversification. Even further, when we distinguish between types of functional managers, the number of product functional managers is negatively related to diversification (the relationship was positive for general managers), but unrelated to IT investments (column 4). In contrast, the number of administrative functional managers is strongly positively related to IT investments, but unrelated to diversification (column 5).

The fact that these relationships vary by type of position allows us to rule out that we are just capturing a spurious correlation driven by the fact that the CEO span of control, diversification and investments in IT are all trending up over time. If the correlation was simply spurious, we shouldn't see these differences given that all types of positions increasingly report directly to the CEO over time. ${ }^{19}$

\footnotetext{
${ }^{19}$ We also performed a number of additional robustness tests/additional specifications (unreported): The results are similar when using CEO rather than firm fixed effects and when using a Poisson count model rather than OLS; There are no significant differences between manufacturing and services firms; the effects are mainly contemporaneous or appear with a one year lag (i.e. organizational changes occur in the same year or a year after the IT and diversification changes, never before). Results are available upon request.
} 
To further evaluate the relationship between diversification, IT and types of functional managers reporting to the top, we turn to Table 4 where we use additional measures of firm diversification and IT investments. First, in Columns 1 and 5 of Table 4, we replicate the basic specification of Columns 4 and 5 in Table 3, by adding as a further control the number of general managers to account for the possible overall increase in span. As before, we see that while diversification (as measured by entropy) is negatively correlated with the number of product functional managers (Column 1), it is uncorrelated with number of administrative functional managers (Column 5). A one standard deviation increase in diversification is associated with a decrease of 0.10 product functional managers, or 16 percent of the standard deviation in the number of product functional managers. In contrast, IT adoption is positively correlated with the number of administrative functional managers (Column 5), but not with the number of product functional managers (Column 1). A one standard deviation increase in IT is associated with a decrease of 0.12 administrative functional managers, or 9 percent of the standard deviation in the number of administrative functional managers. ${ }^{20}$

Second, in Columns 2, 3, 6 and 7, we reproduce these results with two alternative measures of firm diversification. Using both measures of vertical relatedness (Columns 2 and 5) and of complementarity (Columns 3 and 6), we find that firms that focus their businesses (less diversified) increase the number of product functional managers reporting directly to the CEO. The result is stronger for complementarity than vertical relatedness, suggesting that it is the overlap of businesses supplying to the same industries (or procuring inputs from similar industries) rather than their relationship in the vertical chain that matters for coordination and the realization of synergies. Yet, for administrative functional managers, we find the opposite sign on the coefficients of all diversification measures, although they are never statistically significant.

Finally, we recognize that PC per employee is a crude measure of IT as a facilitator of communication. A better measure is available, but only from 1993: This is the number of Local Area Network nodes. In Columns 4 and 8 we add the logarithm of LAN nodes as an independent variable to our main specification (for the year prior to 1993 we impute a value of zero and dummy out the imputed observations in order to keep the number of observations constant between columns 1 and 4, and 5 and 8). We find that using the number of LAN nodes gives similar results as PCs per employee: it increases the number of functional managers reporting to the CEO, but has no effect on product functional managers. The magnitude of the effect is also quite large: a one standard deviation increase in ln nodes leads to 0.41

\footnotetext{
${ }^{20}$ We also tested and rejected the notion that the relationship between the number of functional managers and IT is just driven by the increasing importance of the Chief Information Officer (CIO) position. When we regress an indicator variable representing whether the CIO directly reports to the CEO on PC per employee and all of the controls in our specification of Table 3, we find a small and statistically insignificant coefficient on PC per employee.
} 
more administrative functional managers (30 percent of the standard deviation). This suggests that the communication component of IT matters most for the functional centralization of administrative positions.

How do we interpret our findings? Some results are at odds with simple explanations of the relationships between the structure of the top team, firm diversification, and IT investments. Instead, we interpret our findings, and specifically the differences by type of manager, to be broadly consistent with the explanation discussed in Section II-B. As expected, diversifying firms increase both the size of the team and the number of general managers: as firms diversify they increase the number of general managers who manage businesses and this adds to team size. What is surprising is that firm scope is not related to the overall number of functional managers. A simple synergy argument suggests that firms that focus their businesses increase the number of functional managers because of increased opportunities for synergies and additional gains from coordination across business units. This is not at all the case if we just look at the total number of functional managers (in fact, if anything, we find the opposite result in Table 3, Column 3).

Most notably, when we split the functional managers into product and administrative, we find that firms that focus their businesses increase the number of product functional managers (consistent with synergies or scope economies), but that firm scope has no effect on administrative functional managers. This is consistent with the notion that different functions use different types of information. For product functions (e.g., marketing and $R \& D$ ) that rely on product-specific information, there are greater gains from centralizing the function at the top when firms are focused because information is similar. In contrast, administrative functions (e.g., finance, HR) are not as responsive to changes in firm scope because they use little product-specific information. These results highlight the importance of distinguishing between types of managers and the nature of the information used in performing their activities/tasks when analyzing the organizational choices of firms.

We also find systematic differences across types of functional managers for IT investments, consistent with differences in the nature of the information used by the different functions: IT investment increases the number of functional managers in the top team, and in particular, administrative functional managers (but is negatively related to the number of general managers). So, IT-intensity is correlated with the composition of the top team, specifically administrative functional managers, but not with the size of the team. The fact that IT is not correlated with team size is at odds with predictions of some theories and the simple logic that IT should increase CEO capacity to manage more subordinates. Again, our findings highlight the importance of distinguishing between types of positions and types of tasks. To the extent that IT facilitates communication within the firm, our findings suggest that as communication costs fall, firms centralize administrative functions (e.g., finance and HR) at the top regardless of firm scope. 
Synergies (or scale economies in IT) are easier to exploit in administrative functions because information is less product-specific and can be more easily aggregated. Lower communication costs, in turn, do not drive the centralization of product functions, since the information is harder to aggregate. ${ }^{21}$

A related interpretation of our IT results is that administrative functions use less "soft", tacit, or non-codifiable information. As shown by Stein (2002), decentralization is optimal when information is "soft," and IT investments should favor the centralization of activities that use "hard" information. Hence, IT investments centralize administrative functions that use "hard" information, but have little effect on product functions that use "soft" information. Building on this, if IT facilitates the outsourcing of activities because it makes monitoring easier as information is hardened, and if it is easier to harden information in administrative functions, then some of the functional centralization we observe could also be accompanied by outsourcing functions, with the coordination of outsourced activities now residing at headquarters (e.g., HR, Finance). ${ }^{22}$

All these results are identified from within firm variation in the relevant variables (hence we are controlling for permanent unobserved differences between firms). We also hold a large number of firm characteristics constant, through the regression controls. Some interesting relationships emerge between the controls and the dependent variable. In particular, our control for the degree of competition (the pricecost margin), is related to the presence of general managers at the top: more competitive industries have more general managers reporting to the CEO, but no relationship with functional managers. This is consistent with the reduction in the number of management layers following a trade liberalization found in Guadalupe and Wulf (2010) which we interpret as increased involvement in decision making by division managers when competition, and hence the importance of fast, adapted responses to local information increases. We also find that the larger the share of sales by foreign affiliates (a measure of the degree of internationalization of the firm), the larger the span of control which is driven by a greater number of administrative functional managers. One interpretation is that as US firms increase operations in international product and labor markets, the importance of monitoring and compliance by administrative functional managers increases. Note also that our regressions control for whether the firm

\footnotetext{
${ }^{21}$ We also explored the interaction between IT and the degree of diversification (unreported). Consistent with our interpretation, we found that for product functions, while IT has little effect on average, it is positively related to the number of product functional managers in focused firms, where the product information is more similar across businesses so that it can easily be aggregated. In contrast, this interaction was not significant in regressions analyzing the number of administrative functional managers. These results also hold for our different measures of diversification.

${ }^{22}$ Note we are considering that IT improves vertical communication, but it could also improve horizontal communication between business units (e.g. Cremer, Garicano and Prat, 2007; Dessein and Santos, 2006). In that case, IT investment would typically lead to more activities being performed by business units and hence fewer functional managers at the top, which is the opposite of what we find.
} 
has a Chief Operating Officer (COO) and whether it has a Chief Administrative Officer (CAO). Over our sample period, firms have been eliminating both $\mathrm{COO}$ and CAO positions - which are typically intermediary positions between general managers and functional managers, respectively, and the CEO-and our results could just be reflecting the presence or absence of these positions.

We have shown that changes in the functional centralization of activities within senior management positions in response to changes in firm scope and information technology vary by type of functional manager. Differential results across types of functions allow us to shed light on the role of information in a firm's choice to centralize functions at the corporate-level. Our results show that when analyzing the allocation of activities and decision making within organizations it is crucial to distinguish between types of managerial positions, since they respond to different forces.

\section{B. Understanding Changes to the Top Management Team through Changes in Pay}

After showing how the composition of the senior executive team has changed over time with changes in diversification and IT investments, next we explore what adding a functional manager to the executive team means. To do so, we analyze how pay for our different types of managers (general managers, functional managers and the CEO) changes as their position in the hierarchy (e.g., their reporting level) and the composition of the senior executive team changes. This will allow us to interpret how the allocation of activities within the firm is changing with changes in top team structure.

One advantage of our dataset is that, for some positions (Division Managers, CFO, General Counsel, and Chief HR Officer and CEO), we have information on pay and reporting levels, even if the position is not directly reporting to the CEO. ${ }^{23}$ So, all regressions in Table 5 have a position-year as the basic unit of observation, and have the following structure:

$$
\ln \left(W_{p i t}\right)=\alpha+O_{p i t}{ }^{\prime} \beta+F_{i t}{ }^{\prime} \delta+X_{i t}{ }^{\prime} \theta+d_{t}+d_{p i}+\varepsilon
$$

The dependent variable $\ln \left(W_{\text {pit }}\right)$, is either the logarithm of base compensation (salary) or total compensation (salary, bonus and long-term incentives) of position $p$ in firm $i$, in year $t$. We analyze separately the correlates of pay for three types of positions: general managers (division managers), functional managers, and the CEO. The independent variables include a vector of variables that characterize the position itself $\left(O_{\text {pit }}\right)$ such as whether the position reports to the CEO, and a vector of firm characteristics $\left(F_{i t}\right)$ such as how many functional and general managers report to the CEO, and the types

\footnotetext{
${ }^{23}$ In our firm-level data, for each firm-year, we know which positions report directly to the CEO. For a select group of positions, we know, conditional on the existence of the position, whether it reports directly to the CEO or not. In most cases, for this subset of positions, functional managers report directly to the CEO (72\%), but in $28 \%$ of the cases they do not.
} 
of functional managers (i.e., product or administrative). All regressions include the same set of controls $X_{i t}$ as earlier tables in addition to firm-specific position fixed effects and time dummies such that all the effects are identified within a firm and position as they change over time.

We start describing pay for functional managers, in Columns 1 and 2. As mentioned, the only functional managers we have pay information for are the CFO, the General Counsel and the Chief Human Resources Officer (Administrative functions in our terminology). The variable "Reports to the CEO" is a dummy variable that equals one if the position reports directly to the CEO. Note that when this variable equals zero it means that the position exists elsewhere in the firm, not in the top team. We find that there is an 11 percent increase in base compensation and a 15 percent increase in total compensation when the position joins the executive team by reporting directly to the CEO. One might argue that reporting to the CEO does not mean much, that it is simply a box on a chart with no real consequences. At the very least, our evidence indicates that reporting to the CEO has practical consequences in terms of pay and hence some economic meaning. We interpret this pay increase to suggest that the level of responsibility and authority of the manager is greater when the position becomes part of the executive team. We also find the base salary is 1.5 percent lower for functional managers with each extra functional position that reports to the CEO.

Columns 3 to 6, report pay changes for division (general) managers. Here again, we find that reporting directly to the CEO increases base pay (7 percent) and total compensation (13 percent) for these managers. But even more interestingly, and a central finding in our paper, we find strong evidence that division manager pay decreases as more functional managers report directly to the CEO (Columns 3 and 4). In Columns 5 and 6 we distinguish between the effect of two types of functional managers -administrative and product managers - on division manager pay. We find that the increase in the number of product functional managers is strongly associated with a decrease in division manager's pay: one more product functional manager reporting to the CEO is associated with a 2.4 percent lower salary and 5.4 percent lower total compensation for division managers. In contrast, we find no correlation between administrative functional managers and division manager pay.

While we do not observe the tasks/activities/decisions performed by each of our managers directly, one interpretation of these results is that when more activities/decisions are "centralized" (allocated to the functional manager), division manager pay declines. And this effect is particularly strong for product-related activities like R\&D or marketing (relative to administrative activities), that typically are a more substantial component of the division manager's job. To sum up: First, the role of the functional manager changes as the functional position joins the executive team since their pay increases. Second, since division manager pay declines when there are more product functional managers at the top, 
functional managers serve as substitutes for division managers in product functions, but not in administrative functions.

Finally, we studied how CEO pay evolves with the size and composition of the executive team. The results are presented in Columns 7 and 8. We find some weak evidence that CEO pay, and in particular base pay, declines with the size of the executive team, however the coefficients on the number of general managers and the number of functional managers are quantitatively small and never statistically significant.

Using pay and reporting relationships, we have documented two relevant facts that illustrate what occurs inside the firm as the composition of the CEO's direct reports changes: (i) functional manager and general manager (division manager) pay increases when the position moves closer to the CEO and (ii) division manager pay decreases when more product functional managers report directly to the CEO. These findings are consistent with the interpretation that functional managers centralize functions that previously resided with the business unit or division managers. This is particularly true for product functions, and less so for administrative functions.

These results support the idea that the secular increase in span of control of the CEO, that takes mainly the form of more functional managers reporting directly to the CEO, is reflecting an increase in centralization of decision making at the headquarters of the organization. We are not suggesting that the CEO is more involved in decision-making, but instead that the shift in the composition of the second layer of managers is consistent with a trend toward centralization of functions at the top of the organization to exploit synergies through corporate-wide coordination of functional activities.

\section{Discussion and Conclusion}

We show that CEOs of large US firms radically shifted the composition of their executive teams toward more functional managers since the mid-1980s. The new structure reflects an underlying organizational form that is distinct from the traditional M-form organization (e.g., Chandler, 1962; Williamson, 1975, 1985) prevalent up through the 1990s. Our findings suggest that firms simultaneously narrowed the scope of their business operations, invested in information technology, and restructured their executive teams. Yet, some of our findings are at odds with simple explanations. We document how the different types of managers that comprise the top team - e.g., general managers and functional managers -- respond to changes in firm scope and IT-intensity. As expected, when firms diversify they increase the number of general managers responsible for business units. However, the increase in the number of functional managers varies across type of function. Firms that focus their businesses increase product functional managers, while firms investing in IT increase administrative functional managers. Furthermore, we find that general manager pay decreases as product functional managers join the 
executive team suggesting a shift in activities from general managers to functional managers. Our evidence suggests that the decision to coordinate corporate-wide functional activities in headquarters depends on the relatedness of the businesses, IT-intensity, and the importance of product-specific information in performing activities, and that the response to these variables is highly heterogeneous across positions. Taken together, we interpret our findings as evidence suggesting that firms have centralized functions at the corporate-level to exploit synergies and coordinate activities as they focus their portfolios and increase investments in IT.

An important contribution of this paper is that it bridges between the strategy, organizational economics and top management team literatures as it provides some important guidance to practitioners on how to implement strategy through organizational choices.

First, our findings on changes in structure, firm scope and IT are important for strategy scholars. Consistent with the early literature in the strategy field, we find a connection between strategy and structure (e.g., Chandler, 1962) and how changes in each are driven by shifts in the environment in which firms operate (e.g., Lorsch and Lawrence, 1967). More specifically, we show how different degrees of diversification (e.g., Hill, Hitt, and Hoskisson, 1992; Helfat and Eisenhardt, 2004) and different IT investment levels require different organizational structures. Chandler documented how firms moved away from the U-form to adopt the M-form structure as they diversified; we show a reversal of this trend- firms adopt aspects of the U-form as they focus their business portfolios, with the resulting structure being some hybrid form (e.g., Galbraith, 2002). While we focus on top teams, our findings relate to research on interdependencies between various organizational choices including vertical hierarchy, incentive design, and divisional structures (e.g., Rivkin and Siggelkow, 2003; Puranam and Goetting, 2011) and the literature on complementarities (e.g., Milgrom and Roberts, 1995; Bresnahan, Brynjolfsson and Hitt, 2002; Roberts, 2004; Bartel, Ichiowski and Shaw, 2007).

Second, moving beyond scholars, our findings are critical for practitioners, and specifically CEOs, as they structure their executive teams and more generally as they make decisions to implement or execute strategy. CEOs should design the structure of their top teams based on firm scope and the opportunities for synergies, while recognizing the distinction between different types of functions and the importance of the nature of the information that is required to perform different activities.

Third, our evidence of a radical shift in the composition of executive teams of large US firms is central to the extensive literature in management on top management teams (TMT) (e.g., Hambrick and Mason, 1984). Much of this research examines the effects of demographic diversity among senior managers on organizational outcomes based on the assumption that the interactions between different types of managers affect the decisions that they make. However, the literature is silent on the structure and composition of the managerial positions that comprise the top team and does not consider that the top 
team composition is actually reflecting the firm's choices regarding organizational structure: choices in terms of the decision to centralize or decentralize decision-making and to organize as a U-form, M-form or something different. Our findings suggest that, in conjunction with demographic diversity, it would be beneficial for TMT scholars to explore how the positions that comprise the team relate to these broader organizational choices.

Finally, our evidence on differential effects across types of managers suggests that the existing theoretical models in economics overlook important subtleties in the way organizations work. By ignoring the structure of the top team and the differences between types of managers, the formal models may be too simplistic and misleading in their predictions. At minimum, the implicit assumptions of the formal models that managerial positions are homogeneous is at odds with the findings that we document. Our evidence implies that it is critical to distinguish between types of positions at the top of the hierarchy and the nature of the tasks they perform in modeling a firm's decisions about top team structure and organizational form. In particular, it is important to make distinctions not only between general ("line”) managers and functional ("staff") managers in the organization, but also between different types of functional managers.

Taken together, our findings from this paper and prior related work suggest that the standard classification of firms as being either "centralized" or "decentralized" is too simple to accurately represent the organizational changes firms undergo at the top of the organization. Instead, the evidence suggests that firms are doing both. General managers of business units perform more activities as they move closer to the CEO which is reflected in higher pay and a higher fraction of firm-performance based pay (Rajan and Wulf, 2006; Guadalupe and Wulf, 2010)-- consistent with decentralization or delegation to general managers. Yet, as shown in this paper, there are also more functional managers in the executive team coordinating across business units and performing some activities of the general manager's job which is reflected in lower pay for general managers-- consistent with centralization of certain functional activities within headquarters. Furthermore, CEOs seem to be more involved in internal operations in firms with broader spans of control (Wulf, 2011; Bandiera, Prat, Sadun and Wulf, 2011) —again a form of centralization. A better understanding of the internal operations of firms and the activities performed by managers will require more detailed data (e.g., Bandiera, Prat, Sadun and Wulf, 2011).

While we focus on trends that alter the firm's ability to create and exploit synergies, there are certainly other changes in the firms' competitive environment explaining the dramatic shift in the importance of functional managers, but unrelated to synergies. For example, firms may face more complex problems over time (e.g., Nickerson and Zenger, 2005) that require specialized knowledge within the firm (Hayek, 1945) and particularly within the members of the executive team. Or, the shift to a service-based economy that relies on human capital and knowledge as the critical resource instead of 
physical capital potentially has implications for organizational structure at the top (e.g., Rajan and Zingales, 2001). Finally, advances in information technology that are complementary with cognitive, nonroutine tasks, but substitutes with routine tasks (Autor, Levy and Murnane, 2003) and that affect the ability to outsource certain aspects of production, may affect the optimal organizational structure and the types of skills needed in executive ranks. Exploring further the implications of these alternative mechanisms is left for future research. 
Figure 1: IBM Senior Executive Team, 1994

Legend

Functional Specialists

General Managers

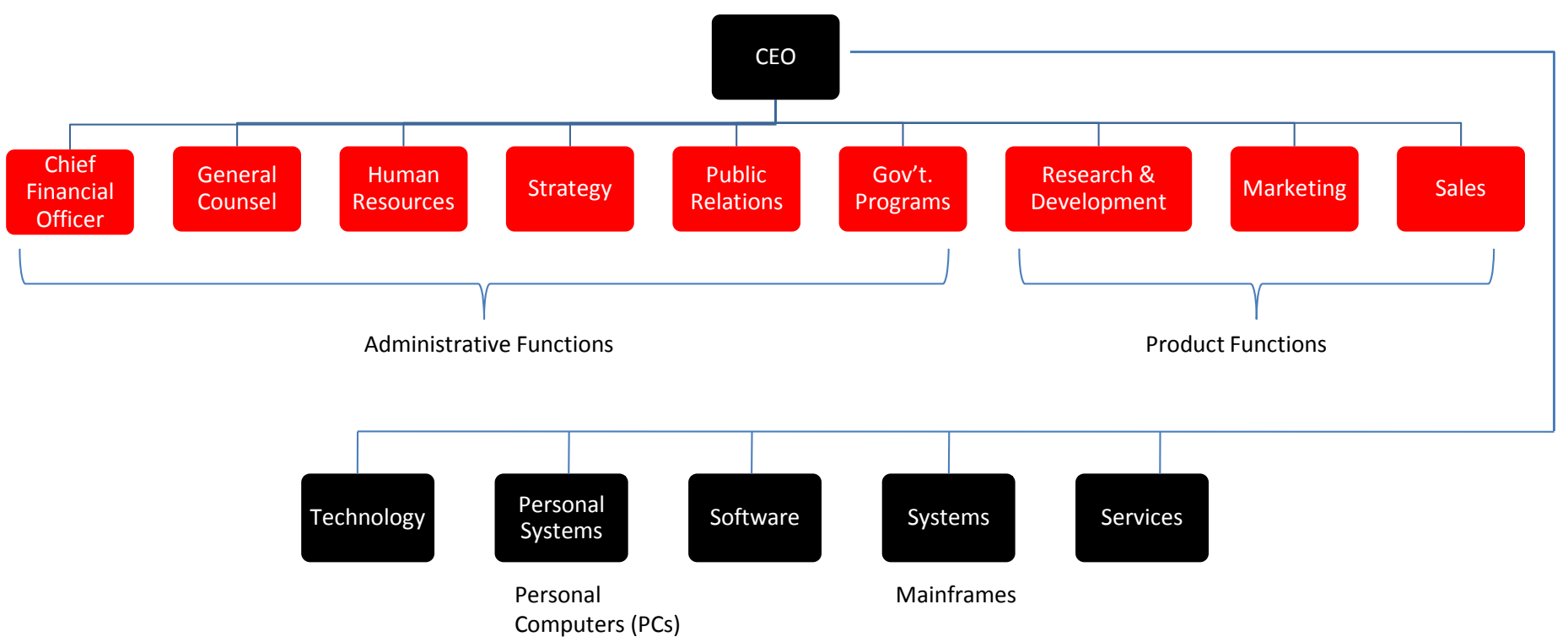

Source: IBM

Notes: Of the 14 that reported directly to the CEO, 5 were general managers and 9 were functional managers. The administrative functional managers are CFO, General Counsel, Human Resources, Strategy, Public Relations, and Gov’t Programs. The product functional managers are Research \& Development, Marketing, and Sales. 
Figure 2: Span, Functional Managers and General Managers over Time (1986-2006) (sample averages)

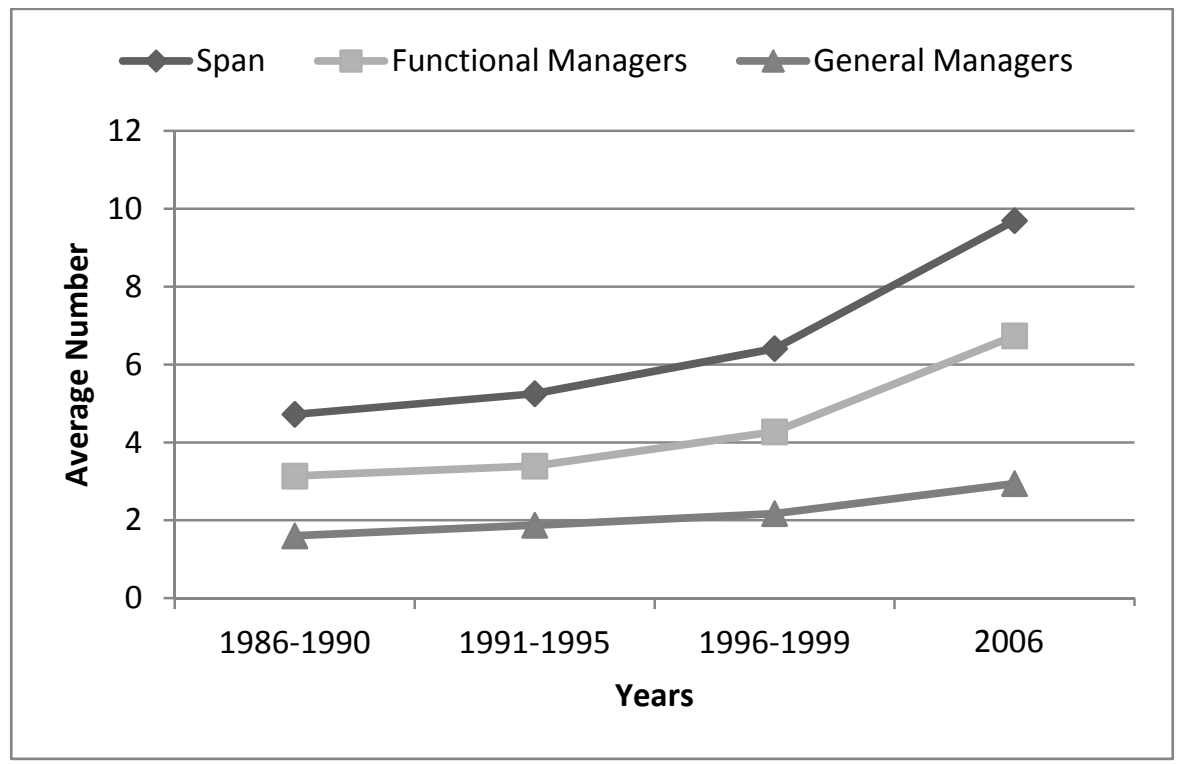

Note: To minimize bias from using an unbalanced panel, the figure above is based on the sample of firms that appear for at least 10 years over the sample period. The first three time periods use data from the larger sample of firms (290), while the last time period (2006) is based on smaller sample (43 firms). If we limit the sample to only the 43 firms for which we have data in the later period, the pattern over the 20 years is qualitatively similar. Where we could not find 2006 data, we took the nearest year to 2006 between 2004 and 2008. 
Table 1: Mean and Correlations between Top Management Team Positions

\begin{tabular}{|c|c|c|c|c|c|c|c|c|c|}
\hline & $\begin{array}{c}\text { Mean } \\
(1) \\
\end{array}$ & $\begin{array}{c}\text { Gen. Mgrs. } \\
\text { (2) }\end{array}$ & $\begin{array}{l}\text { CFO } \\
(3)\end{array}$ & $\begin{array}{c}\text { General } \\
\text { Counsel } \\
(4) \\
\end{array}$ & $\begin{array}{c}\text { CHRO } \\
(5) \\
\end{array}$ & $\begin{array}{c}\text { Strat. } \\
\text { Planning } \\
(7)\end{array}$ & $\begin{array}{c}\text { Sales \& } \\
\text { Marketing } \\
(8) \\
\end{array}$ & $\begin{array}{l}R \& D \\
(9) \\
\end{array}$ & $\begin{array}{c}\text { Manufacturing } \\
\text { (10) } \\
\end{array}$ \\
\hline General Mgrs. & 1.790 & 1 & & & & & & & \\
\hline \multicolumn{10}{|l|}{ Admin. Functions: } \\
\hline CFO & 0.728 & $0.12 * * *$ & 1 & & & & & & \\
\hline General Counsel & 0.672 & $0.11^{* * *}$ & $0.29 * * *$ & 1 & & & & & \\
\hline CHRO & 0.522 & $0.13^{* * *}$ & $0.19 * * *$ & $0.29 * * *$ & 1 & & & & \\
\hline CIO & 0.063 & $0.08^{* * *}$ & $0.074 * * *$ & 0.04 & $0.14^{* * *}$ & & & & \\
\hline Strat. Planning & 0.237 & $0.14^{* * *}$ & $0.07 * *$ & 0.03 & $0.08^{* * *}$ & 1 & & & \\
\hline \multicolumn{10}{|l|}{ Product Functions: } \\
\hline Sales \& Marketing & 0.113 & -0.02 & -0.013 & -0.03 & 0.02 & -0.01 & 1 & & \\
\hline $\mathrm{R} \& \mathrm{D}$ & 0.150 & $0.10^{* * *}$ & $0.09 * * *$ & 0.04 & $0.06^{* *}$ & $0.08^{* * *}$ & $0.08^{* * *}$ & 1 & \\
\hline Manufacturing & 0.053 & 0.01 & $-0.04 *$ & $-0.06^{* *}$ & -0.01 & 0.03 & $0.21^{* * *}$ & $0.14^{* * *}$ & 1 \\
\hline
\end{tabular}

Notes: $* * *, * *$, and $*$ represent statistical significance at $1 \%, 5 \%$, and $10 \%$ levels respectively. The following variables are included in this table: General managers is the number of general managers (includes $\mathrm{COO}$, group managers and division managers) reporting directly to the CEO; All other variables are dummy variables for whether a given functional position reports directly to the CEO. CFO stands for Chief Financial Officer, CHRO stands for Chief Human Resource Officer, and CIO stands for Chief Information Officer. For each of these functions (Administrative and Product), the mean (Column 1) represents the fraction of the sample that has the position reporting directly to the CEO. Columns 2 through 10 show the correlation between pairs of positions. 
Table 2: Descriptive Statistics

\begin{tabular}{lrrc}
\hline & Mean & S.D. & Observations \\
\hline Firm variables: & & & \\
Sales (000s) & 9267.44 & 16106.13 & 2321 \\
Assets (000s) & 10826.57 & 21852.34 & 2329 \\
Number of Employees (000s) & 48.28 & 81.36 & 2329 \\
Number of Segments & 2.76 & 1.66 & 2329 \\
Functional Managers & 3.19 & 1.53 & 2329 \\
Administrative Functional Managers & 2.55 & 1.41 & 2329 \\
Product Functional Managers & 0.32 & 0.60 & 2329 \\
General Managers & 1.79 & 1.52 & 2329 \\
Span (Size of Top Management Team) & 4.98 & 2.34 & 2329 \\
CAO & 0.33 & 0.47 & 2329 \\
COO & 0.48 & 0.50 & 2329 \\
PCs per Employee & 0.22 & 0.21 & 2329 \\
Industry Avg. Price-Cost Margin & 0.18 & 0.10 & 2321 \\
Foreign Affiliates Sales (\%) & 0.23 & 0.21 & 2329 \\
ln Number of LAN nodes & 4.25 & 4.03 & 2329 \\
Firm scope variables: & & & \\
Unrelated Diversif. (Entropy) & 0.37 & 0.41 & 2329 \\
Vertical Relatedness & 0.02 & 0.04 & 1502 \\
Complementarity & 0.40 & 0.31 & 1502 \\
Compensation variables: & & & \\
ln Func. Mgrs. Base Compensation & 12.43 & 0.38 & 5317 \\
ln Func. Mgrs. Total Compensation & 13.28 & 0.70 & 5317 \\
ln General Mgrs. Base Compensation & 12.05 & 0.41 & 8866 \\
ln General Mgrs. Total Compensation & 12.75 & 0.65 & 8866 \\
ln CEO Base Compensation & 13.49 & 0.35 & 2340 \\
ln CEO Total Compensation & 14.65 & 0.75 & 2340 \\
\hline
\end{tabular}

Notes: Number of segments is the number of business segments (COMPUSTAT segment data). Functional managers is the number of functional manager positions reporting directly to the CEO. Administrative functional managers include CFO, General Counsel, Human Resources, Public Relations, Planning, and Chief Information Officer. Product functional managers include heads of R\&D, marketing, sales, sales \& marketing, and manufacturing. General managers is the number of general managers reporting directly to the CEO (COO, group managers and division managers). Span is the total number of positions reporting directly to the CEO. PCs per employee is PCs per 1000 employees. The Industry average price-cost margin is computed at 3-digit SIC (COMPUSTAT). Foreign Affiliate Sales (\%) is the fraction of sales reported by foreign affiliates as a share of total firm sales (COMPUSTAT Geographic Segment data). In Number of LAN nodes is the log of the number of Local Area Network nodes. Unrelated diversification is the entropy measure used in Palepu (1985). Vertical Relatedness and Complementarity are based on Fan and Lang (2000) definitions, using 1992 US Input-Output tables and COMPUSTAT segment data. See footnotes 13, 14 and 15 for exact definitions. Base Compensation is an employee's base salary, while Total Compensation includes base salary along with bonuses and long-term incentives. 
Table 3: Changes in the Composition of the Top Management Team

\begin{tabular}{|c|c|c|c|c|c|}
\hline & $\begin{array}{l}\text { Span } \\
(1)\end{array}$ & $\begin{array}{c}\text { General Mgrs } \\
(2)\end{array}$ & $\begin{array}{c}\text { Func. Mgrs } \\
\text { (3) }\end{array}$ & $\begin{array}{c}\text { Product } \\
\text { Func. Mgrs. } \\
(4)\end{array}$ & $\begin{array}{c}\text { Admin. } \\
\text { Func. Mgrs. } \\
\text { (5) }\end{array}$ \\
\hline Unrelated Diversif. (Entropy) & $\begin{array}{l}0.741 * \\
(0.411)\end{array}$ & $\begin{array}{c}0.625 * * \\
(0.270)\end{array}$ & $\begin{array}{c}0.116 \\
(0.297)\end{array}$ & $\begin{array}{c}-0.262 * * \\
(0.133)\end{array}$ & $\begin{array}{c}0.378 \\
(0.245)\end{array}$ \\
\hline PCs per Employee & $\begin{array}{c}0.268 \\
(0.440)\end{array}$ & $\begin{array}{l}-0.370 \\
(0.245)\end{array}$ & $\begin{array}{c}0.638 * * \\
(0.301)\end{array}$ & $\begin{array}{l}0.0902 \\
(0.134)\end{array}$ & $\begin{array}{c}0.548 * * \\
(0.236)\end{array}$ \\
\hline $\ln$ (Sales) & $\begin{array}{l}-0.381 \\
(0.349)\end{array}$ & $\begin{array}{l}-0.0186 \\
(0.217)\end{array}$ & $\begin{array}{l}-0.363 \\
(0.234)\end{array}$ & $\begin{array}{c}-0.122 \\
(0.0809)\end{array}$ & $\begin{array}{l}-0.241 \\
(0.205)\end{array}$ \\
\hline \# of Segments & $\begin{array}{l}-0.0551 \\
(0.0810)\end{array}$ & $\begin{array}{l}-0.0571 \\
(0.0534)\end{array}$ & $\begin{array}{l}0.00205 \\
(0.0549)\end{array}$ & $\begin{array}{c}0.0423^{* *} \\
(0.0194)\end{array}$ & $\begin{array}{l}-0.0402 \\
(0.0480)\end{array}$ \\
\hline CAO & $\begin{array}{c}0.464 * * \\
(0.183)\end{array}$ & $\begin{array}{c}0.106 \\
(0.117)\end{array}$ & $\begin{array}{c}0.358 * * * \\
(0.121)\end{array}$ & $\begin{array}{c}0.0602 \\
(0.0532)\end{array}$ & $\begin{array}{c}-0.702 * * * \\
(0.0978)\end{array}$ \\
\hline $\mathrm{COO}$ & $\begin{array}{c}-0.870 * * * \\
(0.168)\end{array}$ & $\begin{array}{c}-0.412^{* * *} \\
(0.111)\end{array}$ & $\begin{array}{c}-0.459 * * * \\
(0.106)\end{array}$ & $\begin{array}{c}-0.190 * * * \\
(0.0403)\end{array}$ & $\begin{array}{c}-0.269 * * * \\
(0.0860)\end{array}$ \\
\hline Foreign Affiliates Sales (\%) & $\begin{array}{l}1.595^{* *} \\
(0.672)\end{array}$ & $\begin{array}{c}0.758 \\
(0.487)\end{array}$ & $\begin{array}{c}0.837 * * \\
(0.407)\end{array}$ & $\begin{array}{c}0.103 \\
(0.167)\end{array}$ & $\begin{array}{c}0.734 * * \\
(0.345)\end{array}$ \\
\hline R \& D / Sales & $\begin{array}{l}-5.389 \\
(7.430)\end{array}$ & $\begin{array}{l}-7.024 \\
(5.077)\end{array}$ & $\begin{array}{c}1.635 \\
(4.458)\end{array}$ & $\begin{array}{c}2.759 \\
(1.755)\end{array}$ & $\begin{array}{l}-1.124 \\
(3.990)\end{array}$ \\
\hline $\begin{array}{l}\text { Industry Avg. Price-Cost } \\
\text { Margin }\end{array}$ & $\begin{array}{l}-1.794 \\
(1.616)\end{array}$ & $\begin{array}{c}-1.784^{*} \\
(1.062)\end{array}$ & $\begin{array}{l}-0.0102 \\
(1.019)\end{array}$ & $\begin{array}{l}-0.386 \\
(0.439)\end{array}$ & $\begin{array}{c}0.376 \\
(0.847)\end{array}$ \\
\hline $\begin{array}{l}\text { Year Dummies } \\
\text { Firm FE }\end{array}$ & $\begin{array}{l}\text { Yes } \\
\text { Yes }\end{array}$ & $\begin{array}{l}\text { Yes } \\
\text { Yes }\end{array}$ & $\begin{array}{l}\text { Yes } \\
\text { Yes }\end{array}$ & $\begin{array}{l}\text { Yes } \\
\text { Yes }\end{array}$ & $\begin{array}{l}\text { Yes } \\
\text { Yes }\end{array}$ \\
\hline Observations & 2,321 & 2,321 & 2,321 & 2,321 & 2,321 \\
\hline $\begin{array}{l}\text { Number of Firms } \\
\text { R-squared }\end{array}$ & $\begin{array}{c}290 \\
0.156\end{array}$ & $\begin{array}{c}290 \\
0.084\end{array}$ & $\begin{array}{c}290 \\
0.128\end{array}$ & $\begin{array}{c}290 \\
0.059\end{array}$ & $\begin{array}{c}290 \\
0.168\end{array}$ \\
\hline
\end{tabular}

Notes: $* * *, * *$, and $*$ represent statistical significance at $1 \%, 5 \%$, and $10 \%$ levels respectively. Standard errors are clustered by firm. Span is the total number of positions reporting directly to the CEO (i.e., the sum of functional managers and general managers). General managers is defined the number of general managers reporting directly to the CEO. General managers include COO, group managers and division managers. Functional manager is defined as the number of functional manager positions reporting directly to the CEO. Product functional managers include heads of R\&D, marketing, sales, sales \& marketing, and manufacturing. Administrative functional managers include CFO, General Counsel, Human Resources, Public Relations, Planning, and Chief Information Officer. 
Table 4: Types of Functional Managers, Business Relatedness, and IT

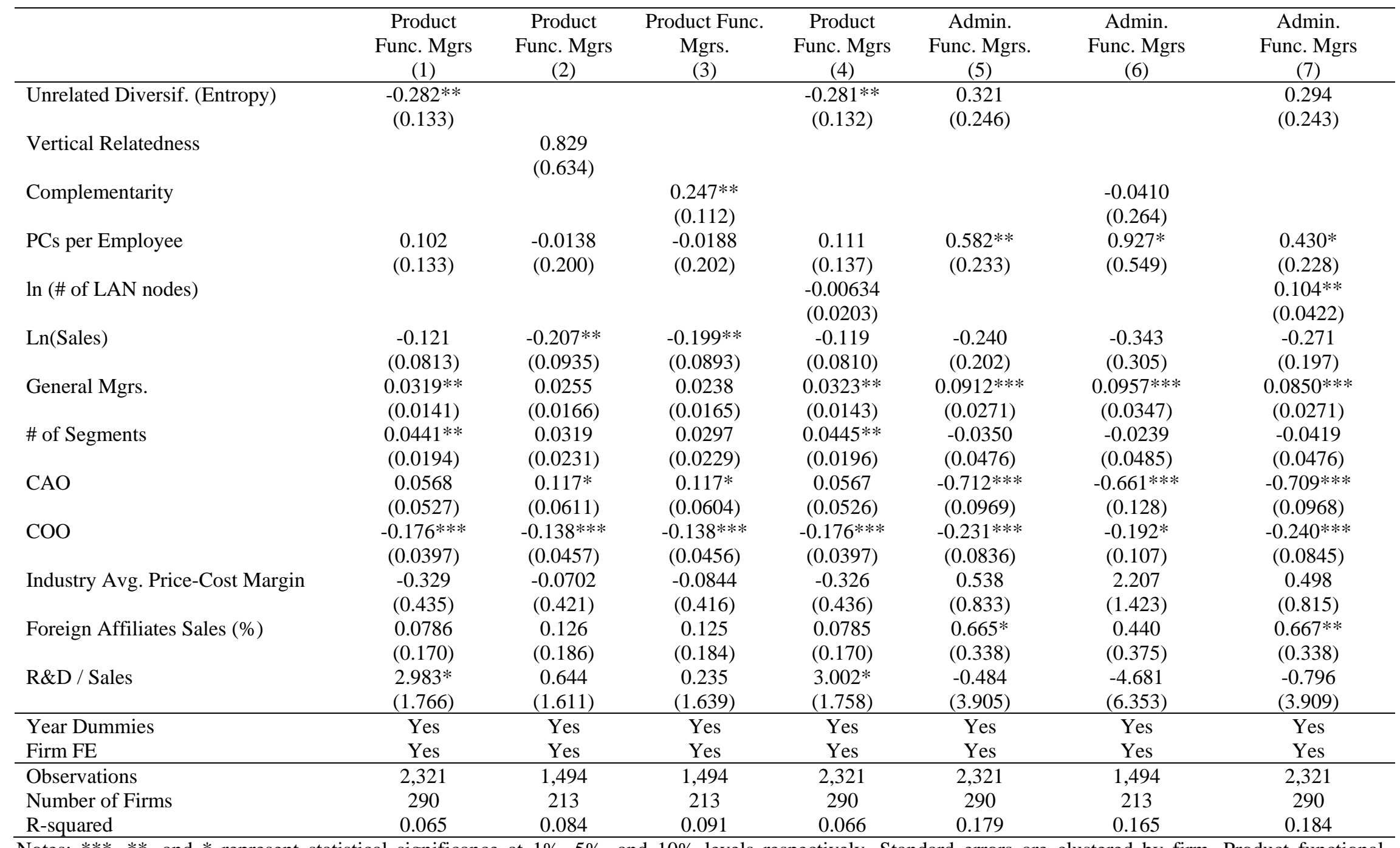

Notes: $* * *, * *$, and $*$ represent statistical significance at $1 \%, 5 \%$, and $10 \%$ levels respectively. Standard errors are clustered by firm. Product functional managers include heads of R\&D, marketing, sales, sales \& marketing, and manufacturing. Administrative functional managers include CFO, General Counsel, Human Resources, Public Relations, Planning, and Chief Information Officer. Since the LAN nodes variable is only available after 1993, we impute a value of zero for the year prior to 1993 and include a dummy variable for the imputed observations in columns 5 and 8 (unreported). 
Table 5: Pay Changes as a Function of Changes in Top Team Structure

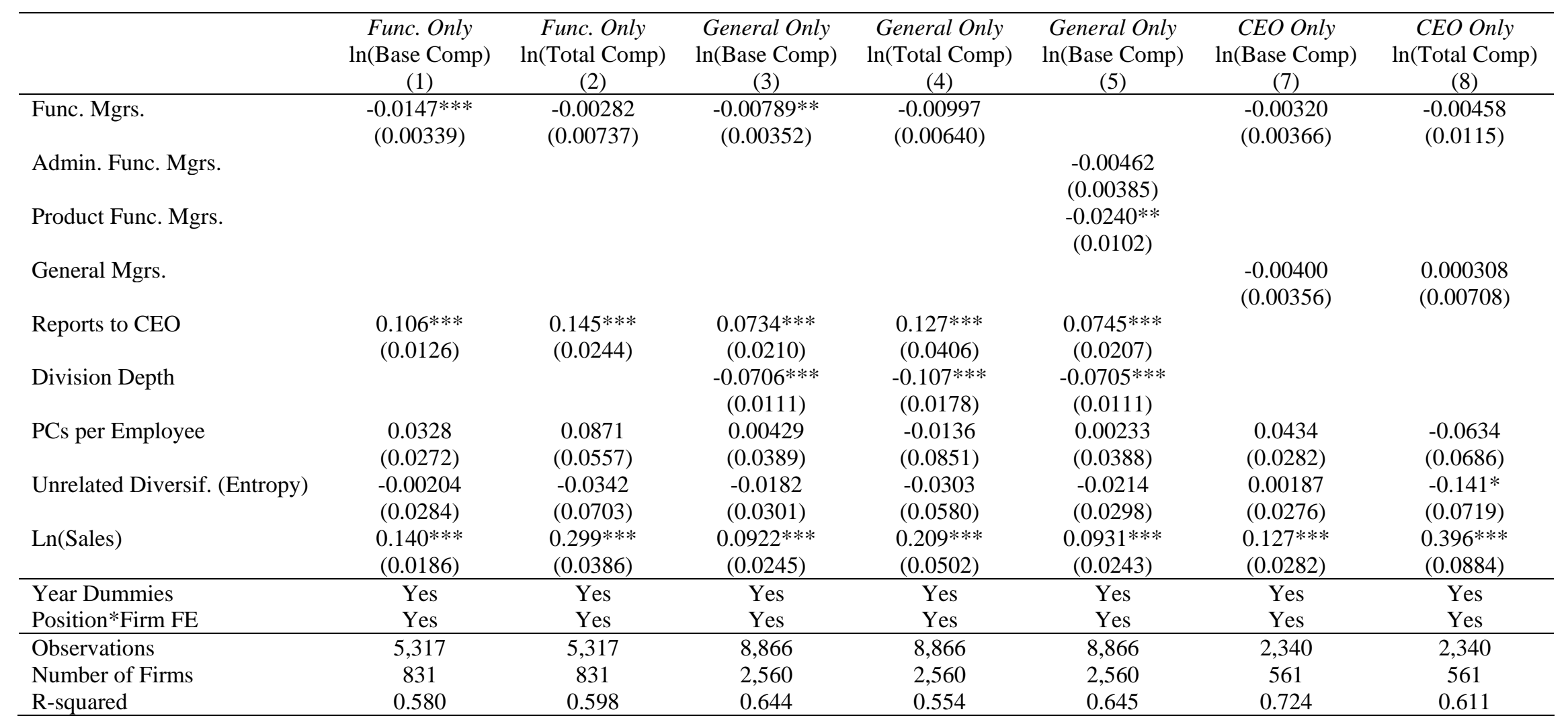

Notes: ***, **, and * represent statistical significance at 1\%, 5\%, and 10\% levels respectively. Standard errors are clustered by firm. Columns 1 and 2 are for the only three functional manager positions for which we have compensation data (CFO, General Counsel, and Human Resources). Columns 3 through 6 only include division (general) managers. Columns 7 and 8 only include CEOs. The variable "Administrative functional managers" includes the CFO, General Counsel, Human Resources, Public Relations, Planning, and Chief Information Officer. The variable "Product functional managers" includes the heads of R\&D, marketing, sales, sales \& marketing, and manufacturing. Base Compensation is an employee's base salary, while Total Compensation includes base salary along with bonuses and long-term incentives. All columns include controls for the number of segments, CAO, COO, Industry Avg. Price-Cost Margin, Foreign Affiliates Sales (\%) and R\&D / Sales, as in earlier tables. 


\section{References}

Argyres, Nicholas S. and Brian S. Silverman (2004). "R\&D, Organization Structure, and the Development of Corporate Technological Knowledge,” Strategic Management Journal, 25 (8/9): 929-958.

Autor, David, Frank Levy and Richard J. Murnane (2003). “The Skill Content of Recent Technological Change: An Empirical Exploration,” Quarterly Journal of Economics, 118 (4): 1279-1334.

Bandiera, Oriana, Andrea Prat, Raffaella Sadun and Julie Wulf (2011). "Span of Control or Span of Activity?” working paper.

Bartel, Ann, Casey Ichniowski, and Kathryn Shaw (2007). "How Does Information Technology Affect Productivity? Plant Level Comparisons of Product Innovation, Process Improvement and Worker Skills,” Quarterly Journal of Economics, 122 (4): 1721-1758.

Bloom, Nicholas, Luis Garicano, Raffaella Sadun, John Van Reenen (2010). "The Distinct Effects of Information Technology and Communication Technology on Firm Organization.” HBS Working Paper.

Bresnahan, Timothy F., Erik Brynjolfsson and Lorin M. Hitt (2002). "Information Technology, Workplace Organization and the Demand for Skilled Labor: Firm-Level Evidence,” Quarterly Journal of Economics, 117 (1): 339-376.

Chandler, Alfred D. (1962). Strategy and Structure: Chapters in the History of the Industrial Enterprise, Cambridge: MIT Press.

(1991). “The Function of the HQ Unit in the Multibusiness Firm,” Strategic Management Journal, 12: $31-50$.

Collis, David J., David Young, and Michael Goold (2007). "The Structure, Size, and Performance of Corporate Headquarters,” Strategic Management Journal, 28 (4): 383-405.

Cremer, Jacques, Luis Garicano and Andrea Prat (2007). "Language and the Theory of the Firm,” Quarterly Journal of Economics, 112 (1): 373-407.

Dessein, Wouter, Luis Garicano and Robert Gertner (2010). “Organizing for Synergies,” American Economic Journal: Microeconomics. 2: 77-114.

Dessein, Wouter and Tano Santos (2006). “Adaptive Organizations,” Journal of Political Economy, 114 (5): 956-995.

Dunne, Timothy and et al (2004). "Wage and Productivity Dispersion in U.S. Manufacturing: The Role of Computer Investment,” Journal of Labor Economics, 22 (2): 397-430.

Fan, J. P. H. and L. H. P. Lang (2000). “The Measurement of Relatedness: An Application to Corporate Diversification.” Journal of Business, 73 (4): 629-660. 
Finkelstein, Sydney, Donald C. Hambrick and Albert A. Cannella Jr. (2009). “Top Management Teams,” In Strategic Leadership: Theory and Research on Executives, Top Management Teams, and Boards, New York: Oxford University Press, p. 121-63.

Fligstein, Neil (1990). The Transformation of Corporate Control. Boston: Harvard University Press.

Galbraith, Jay R. (2002). Designing Organizations: An Executive Guide to Strategy, Structure, and Process, San Francisco: Jossey-Bass.

Garicano, Luis (2000). "Hierarchies and the Organization of Knowledge in Production,” Journal of Political Economy, 108 (5): 874-904.

Gerstner, Louis, Jr. (2002). Who Says Elephants Can’t Dance, New York: Harper Collins, p. 77.

Groysberg, Boris, L. Kevin Kelly and Bryan MacDonald (2011). “The New Path to the C-Suite,” Harvard Business Review, 89 (3): 60-68.

Guadalupe, Maria and Julie Wulf (2010). “The Flattening Firm and Product Market Competition: The Effect of Trade Liberalization on Corporate Hierarchies,” American Economic Journal: Applied Economics, 2 (4): 105-127.

Hambrick, Donald C. and Phyllis A. Mason (1984). "Upper Echelons: The Organization as a Reflection of Its Top Managers,” Academy of Management Review, 9 (2): 193-206.

Harris, M., and A. Raviv (2002). “Organization Design.” Management Science, 48(7): 852-865.

Hart, Oliver and John Moore (2005). “On the Design of Hierarchies: Coordination versus Specialization,” Journal of Political Economy, 113 (4): 675-702.

Hayek, Friedrich A. von (1945). "The Use of Knowledge in Society.” American Economic Review 35: 519-30.

Helfat, Constance and Kathleen Eisenhardt (2004). "Inter-temporal Economies of Scope, Organizational Compliance Coordination in Organizations,” Strategic Management Journal, 25 (13): 1217-1232.

Hill, Charles W. L.; Michael A. Hitt and Robert E. Hoskisson (1992). “Cooperative Versus Competitive Structures in Related and Unrelated Diversfied Firms.” Organization Science, 3(4): 501-21.

Hounshell, David and John Kenly Smith, Jr. (1988). Science and Corporate Strategy: Du Pont R\&D, 1902-1980. New York, NY: Cambridge University Press.

Lawrence, Paul R. and Jay W. Lorsch (1967). Organization and Environment. Boston, Mass.: HBS Division of Research,

Menz, Markus (2011). "Functional Top Management Team Members: A Review, Synthesis, and Research Agenda,” Journal of Management, (forthcoming).

McElheran, Kristina (2010). "Delegation in Multi-Establishment Firms: Evidence from I.T. Purchasing,” Working Paper. 
Milgrom, Paul and John Roberts (1995). "Complementarities and Fit: Strategy, Structure, and Organizational Change in Manufacturing.” Journal of Accounting \& Economics, 19 (2/3): 179-208.

Nath, Pravin and Vijay Mahajan (2008). “Chief Marketing Officers: A Study of Their Presence in Firms’ Top Management Teams,” Journal of Marketing, 72 (1): 65-81.

Nickerson, Jack A. and Todd R. Zenger (2004). “A Knowledge-Based Theory of the Firm--the ProblemSolving Perspective,” Organization Science, 15 (6): 617-32.

Palepu, Krishna (1985). "Diversification Strategy, Profit Performance and the Entropy Measure," Strategic Management Journal, 6 (3): 239-255.

Porter, Michael E. (1985). The Competitive Advantage: Creating and Sustaining Superior Performance, New York: Free Press.

Puranam, Phanish and Marlo Goetting (2011). “Interdependence and Organization Design”, Chapter in forthcoming Handbook of Economic Organization, Ed: Anna Grandori.

Qian, Yingyi and et al (2006). "Coordination and Experimentation in M-Form and U-Form Organizations,” Journal of Political Economy, 114 (2): 366-402.

Rajan, Raghuram G. and Julie M. Wulf (2006). “The Flattening Firm: Evidence From Panel Data On The Changing Nature Of Corporate Hierarchies,” Review of Economics \& Statistics, 88 (4): 769-773.

Rajan, Raghuram G. and Luigi Zingales (2001). “The Influence of the Financial Revolution on the Nature of Firms,” American Economic Review, 91 (2): 206-211.

Rivkin, Jan W. and Nicolaj Siggelkow (2003). "Balancing Search and Stability: Interdependencies among Elements of Organizational Design.” Management Science, 49 (3): 290-311.

Roberts, John (2004). “The Modern Firm.” Oxford University Press.

Rotemberg, Julio J. (1999). "Process-versus Function-Based Hierarchies,” Journal of Economics \& Management Strategy, 8 (4): 453-487.

Rumelt, Richard (1974). Strategy, Structure, and Economic Performance, Cambridge: Harvard University Press.

Sloan, Alfred P. (1963). My Years with General Motors, New York: Doubleday.

Stein, Jeremy (2002). "Information Production and Capital Allocation: Decentralized versus Hierarchical Firms,” Journal of Finance, 57 (5): 1891-1921.

Williamson, Oliver (1975). Markets and Hierarchies, New York: Free Press. (1985). The Economic Institutions of Capitalism, New York: Free Press.

Wulf, Julie. 2011. “The Flattened Firm -Not as Advertised,” Working Paper.

Wulf, Julie. 2011. “The Changing Structure at the Top.” Working Paper.

Zorn, Dirk M. (2004). "Here a Chief, There a Chief: The Rise of the CFO in the American Firm.” American Sociological Review, 69 (3): 345-364. 